\title{
Motivasi Orang Tua Buruh Tani Tehadap Kelanjutan Pedidikan Anak Di Desa Banyu Urip Kecamatan Praya Barat Kabupaten Lombok Tengah
}

\author{
Andi Mulyan \\ Email: Andimulyan2018@gmail.com.
}

\begin{abstract}
Abstrak. Desa Banyu Urip Kecamatan Praya Barat Kabupaten Lombok Tengah memiliki kondisi pendidikan yang masih tergolong rendah. Berangangkat dari permasalahan pendidikan yang terjadi di Desa Banyu Urip Kecamatan Praya Barat Kabupaten Lombok Tengah, penulis mengkaji tentang motivasi orang tua buruh tani terhadap kelanjutan pendidikanan anak. Penulis menggunakan pendekatan kualitatif dengan metode wawancara, observasi dan dokumentas. Ditemukan bahwa ratarata orang tua buruh tani termotivasi untuk menyekolahkan anaknya meskipun mereka berasal dari golongan buruh tani.
\end{abstract}

Kata Kunci: Motivasi Orang Tua Buruh Tani, Kelanjutan Pedidikan Anak

\section{PENDAHULUAN Latar Belakang}

Lingkungan keluarga merupakan salah satu lingkungan pendidikan yang paling utama dan dan pertama. Sebagai lingkungan pendidikan yang pertama karena ketika seorang anak manusia yang terlahir di dunia, tentu mereka pertama kali mendapatkan pendidikan dari orang tua atau keluarga. Demikian juga keluarga sebagai lingkungan pendidikan utama karena anak-anak yang perama kali memasuki lingkungan keluarga di mana mereka mendapatkan pendidikan yang mendasar atau utama di lingkungan keluarga. Namun, dalam mendukung kekuatan pendidikan di dalam kelurga tersebut, yaitu sebagai tempat pendidikan pertama dan utama, motivasi dari keluarga juga sangat dibutuhkan.

Motivasi orang tua sangat dibutuhkan tehadap pendidikan anak agar anak tetap bereran aktif daam menjalankantugasnya sebagai peserta didik hingga mencapai suatu kesuksessan. Dalam dunia pendidikan motivasi sangat dibututuhkan untuk menjadi peyemangat anak, motivasi atau dorongan orang tua kepada anak yang sedang menjalani proses pendidikan menjadi sumber kekuatan agara terus bersemangat dalam belajar.

Desa Banyu Urip Kecamatan Praya Barat Kabupaten Lombok Tengah memiliki kondisi pendidikan yang masih tergolong rendah. Hal ini dapat dilihat dari rata-rata anak muda yang ada di desa ini hanya tammat SD dan SMP. Sementara untuk tammatan SMA masih dapat dihitung jari, dan terlebih jumlah sarjana yang ada di desa ini sangat minim, sehingga rendahnya kuantitas pendidikan berimbas pada indeks pembangunan manusia di wilayah desa ini.

Berangangkat dari permasalahan pendidikan yang terjadi di Desa Banyu Urip Kecamatan Praya Barat Kabupaten Lombok Tengah, penulis mengkaji tentang motivasi orang tua buruh tani terhadap kelanjutan pendidikanan anak. Dari observasi yang dilakukan tentang fenomena pendidikan di Desa Banyu Urip, penulis tertarik untuk melakukan penelitian di desa tersebut dengan judul "Motivasi Orang Tua Buruh Tani Terhadap Kelanjutan Pendidikan Anak Di Desa Banyu Urip Kecamatan Praya Barat Kabupaten Lombok Tengah.

a. Fokus Perrmasalahan

Berdasarkan latar belakang masalah, maka yang menjadi fokus permasalahan dalam penelitian ini adalah Motivasi Orang Tua Buruh Tani Terhadap Kelanjutan Pendidikan Anak Di Desa Banyu Urip Kecamatan Praya Barat Kabupaten Lombok Tengah. 
b. Rumusan Masalah

1. Bagaimana motivasi orang tua buruh tani terhadap kelanjutan pendidikan anak di Desa Bayu Urip Kecamatan Praya Barat Kabupaten Lombok Tengah.

2. Bagaimana keberhasilan orang tua buruh tani dalam memotivasi anak terhadap kelanjutan pendidikan di Desa Banyu Urip Kecamatan Praya Barat Kabupaten Lombok Tengah.

c. Tujuan Penelitian

1. Untuk pengetahui motivasi orang tua buruh tani terhadap kelanjutan pendidikan anak di Desa Banyu Urip Kecamatan Praya Barat Kabupaten Lombok Tengah

2. Untuk mengetahui keberhasilan orang tua buruh tani terhadap kelanjutan pendidikan anak di Desa Banyu Urip Kecamatan Praya Barat Kabupaten Lombok Tengah.

d. Manfaat Penelitian

Penelitian ini diharapkan bermanfaat bagi kita semua baik secara teoritis maupun praktis

1. Manfaat Teoritis

a. Agar hasil penelitian ini dapat memberi gambaran tentang motivasi orang tua buruh tani terhadap kelanjutan pendidikan anak di Desa Banyu Urip Kecamatan Praya Barat Kabupaten Lombok Tengah.

b. Agar melalui tulisan ini, para pembaca yang budiman dapat memahami peran orang tua buruh tani dalam memotivasi anaknya terhadap kelanjutan pendidikan.

2. Manfaat Praktis

a. Agar para orang tua yang berprofesi sebagai buruh tani tetap memiliki rasa kepercayaan diri dan motivasi tinggi terhadap kelanjutan pendidikan anak.

b. Hasil penelitian ini diharapkan bermanfaat bagi masyarakat dan pemerintah, khususnya pada masyarakat Desa Banyu Urip

Kecamatan Praya Barat

Kabupaten Lombok Tengah.

\section{LANDASAN TEORI \\ Pengertian Motivasi}

Motivasi merupakan salah satu hal yang sangat penting bagi setiap individu. Dengan adanya motivasi, seseorang dapat bangkit dari keputus-asaan, karena motivasi juga merupakan suatu hal yang bisa membangkitan seseorang dari keoptimisanya, baik dalam masalah pribadi maupun masalah dengan orang lain secara umum. Motivasi itu sendiri dapat diperoleh seseorang baik secara internal maupun secara eksternal.

Sujono Trimo memberikan pengertian motivasi yaitu suatu kekuatan penggerak dalam perilaku individu, baik yang akan menentukan arah maupun daya tahan. Menurut Chiffrod T.Morgan bahwa motivasi bertalian dengan tiga hal yang sekaligus merupakan aspek-aspek dari pada motivasi. Ketiga hal tersebut adalah keadaan yang mendorong tingkah laku yaitu tingkah laku yang didorong oleh keadaan tersebut, motiving behavior dan tujuan dari tingkah laku tersebut (goal or endsof such behavior).

KBBI, buruh tani adalah orang yang bekerja pada sawah milik orang lain. Mereka biasanya akan bekerja ketika ada pekerjaan di sawah seperti mencangkul atau membersihkan rumput. Mereka juga akan ikut beramai-ramai untuuk menuai padi. Jam kerja pada buruh tani tidak menentu, demikian pula dengan penghasilan yang sangat kecil. Aktifitas sepertiinibanyak di lakoni oleh masyarakat Lombok, terutama di Desa Banyu Urip Kecamatan Praya Barat Kabupaten Lombok Tengah.

Orang tua buruh tani adalah orang tua yang pekerjaan kesehariaannya sebgai buruh tani pada sawah milik orang. Mereka memiliki jam kerja yang tidak beraturan, demikian juga dengan penghasilan yang tergolong kecil. 


\section{METODE PENELITIAN Desain Penelitian}

Desain penelitian menanyakan sebuah sikap yang berkepentingan, dan mempunyai gambaran yang jelas tentang bagaimana keterkaitan antara variabel yang ada pada tugas penelitian dan apa yang hendak dilakukan oleh seseorang peneliti dalam mengumpulkan data.

1. Jenis Pendekatan

Dalam penelitian ini digunakan pendekatan kualitatif. Penelitian kualitatif adalah penelitian yang dilakukan dalam situasi yang wajar dan data yang dikumpulkan umumnya bersifat kualitatif. Pendekatan kualitatif lebih berdasar pada filsafat fenomenologis yang mengutamakan penghayatan. Metode kualitatif berusaha memahami dan menafsirkan makna suatu peristiwa interaksi tingkah laku manusia dalam situasi tertentu menurut prespektif peneliti sendiri (Husnaini Usman, 2004 : 81) dengan bahasa yang sederhana. Zuriah (2007:91) mengatakan bahwa pendekatan kualitatif adalah pendekatan penelitian yang lebih banyak menggunakan logicahipotetiko-verifikatif.

2. Jenis Penelitian

Jenis penelitian yang digunakan dalam penelitian ini adalah penelitian dasar atau murni. Jujun S.Suriasumantri (1985) menyatakan bawa penelitian dasar atau murni yaitu penelitian yang bertujuan untunk menemukan pengetahuan baru yang sebelumnya belum pernah diketahui (Sugiono 2007:4). Penelitian dasar untuk mngembangkan teori dan tidak memperhatikan kegunaan yang langsung bersifat praktis.

\section{Lokasi Penelitian}

Penelitian ini dilakukan di Desa Banyu Urip Kecamatan Praya Barat. Peneliti memilih lokasi penelitian tersebut karena banyaknya ditemukan anak yang kurang mendapatnkan motivasi entah dari diri sendiri maupun dari orang tua untuk melanjutkan pendidikanya kejenjang selelanjutnya atau ke jenjang yang lebih tingi.

\section{Subyek Penelitian}

Peneliti dalam penelitian ini merupakan instrument kunci yang memiliki peran yang sangat utama dalam keseluruhan proses penelitian karena setelah memperoleh data, peniliti tidak langsumg menyajikan data dalam laporan, melainkan peneliti harus mengkonfirmasikan dahulu dengan sumber informan untuk mendapat data yang benar dan akurat. Adapun sumber data dalam penelitian ini adalah subyek dimana data ini diperoleh (Arikunto,2002:106). Subyek dalam penelitian ini adalah bagaimana motivasi dari orang tua kepada anaknya baik yang sedang menempuh pendidikan maupun yang putus sekolah.

\section{Jenis Data dan Sumber Data}

a. Data primer, yaitu data yang diperoleh melalui obsrvasi dan wawancara langsung di tempat kejadian dan tanya jawab terhadap warga setempat tentang motivasi orang tua terhadap pendidikan anak.

b. Data sekunder adalah data yang diperoleh melalui dokumentasi, yang merupakan data sekunder adalah data yang diperoleh dari kantor desa ataupun dari instansi lain yang terkait dengan objek yang akan diteliti yakni bagaimana motivasi orang tua terhadap pendidikan anak.

\section{Tehnik Pengumpulan Data}

\section{Data Primer}

Data primer adalah data yang diperoleh dan dikumpulkan secara langsung dari sumber-sumber asli, dalam hal ini pemerintah desa dan seluruh masyarakat yang dapat memberikan data yang dibutuhkan peneliti yang sesuai masalah dalam penelitian. Cara pengumpulan sebagai berikut.

a. Wawancara 
Wawancara adalah mencari informasi tentang suatu hal dengan mengajukan pertanyaan (narasumber) secara detail. Wawancara digunakan sebagai tekhnik pengumpulan data apabila peneliti ingin mendapatkan dan mengetahui hal-hal dari informan secara lebih mendalam dan jumlah informan sedikit.

b. Observasi

Observasi adalah suatu proses yang kompleks, yaitu suatu proses yang tersusun dari berbagai proses biologis dan psikologis. Dua diantaranya yang terpenting adalah proses-proses dan ingatan. Dari segi proses pelaksanaan pengumpulan data, observasi dapat dibedakan menjadi dua yaitu observasi dan non partisipasi observasi, selanjutnya dari segi instrumentasi yang digunakan maka observasi dibedakan menjadi observasi terstruktur dan tidak struktur.

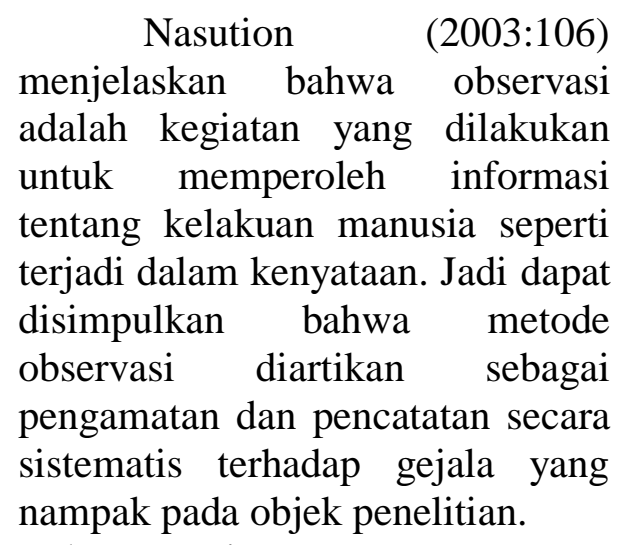

c. Dokumentasi

Menurut Moleong (:161) bahwa dokumentasi adalah setiap pertanyaan tertulis yang disusun oleh seseorang atau lembaga untuk keperluan pengujian peristiwa atau akunting. Jadi dapat disimpulkan bahawa metode dokumentasi adalah suatu tehnik pengumpulan data yang digunakan sebagai acuan dalam mencari dan referensi yang berkenaan langsung dengan masalah dalam penelitian. Adapun yang dijadikan data penunjang dalam penelitian ini adalah berupa buku-buku, catatan atau jenis dokumentasi tertulis lainya, seperti profil desa, foto-foto, dan catatan atau agenda yang dibuat oleh tokoh yang ada di desa.

2. Data Sekunder

Data sekunder adalah data yang dikumpulkan oleh lembaga-lembaga yagn terkait dan dipublikasikan berupa bacaan atau literatur yang berkaitan dengan penelitian ini. Pengumpulan data sekunder salah satunya studi perpustakaan.

\section{Uji Keabsahan Data}

Untuk menetapkan keabsahan data diperlukan tehnik pemeriksaan. Menurut Moleong (2002:173) ada empat kriteria yang digunakan untuk memeriksa keabsahan data, yaitu derajat kepercayaan, keteralihan, kebergantungan, dan kepastian. Berdasarkan penjelasan tersebut maka dalam penelitian ini penelitis menggunakan tehnik keabsahan data yang sesuai dengan kriteria yang telah disebutkan di atas dimana peneliti memperhatikan tingkat kepercayaan data, kepastian data, ketergantungan antara data yang satu dengan data yang lainya, dan kepastian data yang telah terkumpul.

Dalam penelitian ini, data yang dikumpulkan adalah data-data yang bersifat alamiah dimana data-data yang terkumpul lebih banyak didapatkan dari informan yang kadang-kadang memiliki keterbatasan karena disebabkan oleh keletihan atau keterbatasan mengingat dapat menyebabkan kekeliruan, sehingga peneliti perlu memperhatikan keteralihan dan kebergantungan yang juga sering disebut dengan validitas dan reliabilitas data. Selain itu perlu juga diperhatikan kepastian objektivitas (sumber) dimana dalam hal ini peneliti melakukan seleksi terhadap data-data yang telah diberikan oleh nara sumber dan tidak tergantung kepada pandangan atau persetujuan 
seseorang serta berusaha mencari keterangan dari nara sumber yang jujur, faktual, dan dapat dipastikan keteranganya.

Setelah data terkumpul dan sudah diuji keabsahannya maka data-data tersebut perlu diorganisasikan, diseleksi, dan kemudian disusun dalam bentuk tulisan. Meskipun datanya cukup variatif namun dengan dilakukanya dengan pengecekan keabsahan data dengan kriteria-kriteria yang telah ditetapkan sebelumnya maka data yang diperoleh betul vailid dan akurat. Dalam penelitian ini data-data yang telah diperoleh dilapangan nanti akan dibandingbandingkan kemudian dianalisis untuk menarik generalisasi atau kesimpulan.

\section{Tehnik Analisis Data}

Analisis data dalam penelitian merupakan sesuatu kegiatan yang sangat penting dan memerlukan ketelitian serta kekritisan dari penulis.

Dari pengertian di atas, maka untuk mnganalisis hasil penelitian dalam laporan ini menggunakan analisis induktif. Pendekatan induktif adalah suatu analisis data yang memungkinkan temuan-temuan penelitian muncul dari keadaan umum, tema-tema dominan dan signifikan yang ada dalam data tanpa menagabaikan halhal yang muncul oleh struktur bioligisnya. Jadi metode ini sangat tepat bila digunakan untuk menganalisis data yang dimulai dengan gejala-gejala yang sifatnya umum kemudian diuraiakan menjadi kesimpulan yang sifatnya khusus.

\section{PEMBAHASAN}

\section{A. Motivasi Orang Tua Buruh Tani Terhadap Kelanjutan Pendidikan Anak.}

Motivasi dipandang sebagai dorongan mental yang menggerakkan, menyalurkan, mengarahkan sikap dan prilaku manusia, termasuk prilkau belajar. Dalam motivasi terkandung adanya keinginan dalam sikap dan prilaku individu belajar. Dalam hal ini dapat dipahami bahwa motivasi merupakan suatu usaha yang disediakan ke dalam suatu situasi tertentu yang akan diberikan kepada seseorang agar dapat giat dan mengembangkan potensi-potensi yang dimiliki serta memberikan arah yang jelas terhadap tujuan yang hendak dicapai agar kebutuhan dapat terpenuhi.

Berdasarkan hal tersebut di atas, yang mana pada orang tua yang ada di Desa Banyu Urip Kecamatan Praya Barat Kabupaten Lombok Tengah sangat disibukkan oleh waktu demi mencari penghidupan di sawah. Terkadang mereka berangkat dini hari ke sawah, dan saat jelang magrib baru pulang ke rumahnya. Hal ini memberi gambara gambaran jika orang tua buruh tani tidah memiliki waktu yang banyak untuk berkomunikasi dengan anak-anak mereka. Demikian juga pada ibu-ibu buruh tani, mereka juga disibukkan oleh waktu untuk membantu sang suami bekerja di sawah, dan atau membenahi peralatan sawah yang mereka punya. Terkadang mereka sering mengajak anakanak mereka untuk pergi ke sawah sehingga meninggalkan jam pembelajaran di sekolah. Hal ini tentu sangat mencurigakan bahwa motivasi orang tua yang berprofesi sebagai buruh tani agak kurang terhadap pendidikan anak.

Berdasarkan dengan hasil wawancara dan pengamatan, yaitu khusunya tentang motivasi orang tua yang berprofesi sebagai buruh tani terhadap pendidikan anak ternyata tidak sesuai dengan apa selama ini menjadi kecurigaan, yaitu bahwa mungkin mereka memiliki motivasi yang sangat rendah terhadap pendidikan anak. Justru, walaupun mereka disibukkan oleh waktu di sawah, namun mereka tetap bersemangat dan termotivasi untuk menyekolahkan anaknya. Mereka mencari rezeki di sawah yang mana sebagian untuk memenuhi kebutuhan rumah tangga mereka, dan sebagian untuk dipergunakan sebagai biaya pendidikan anak-anak mereka. 
Terkadang para orang tua yang berprofesi sebagai buruh tani di Desa Bayu Urip mengajak dan mengajarkan anakanak mereka untuk belajar bersawah, atau mencari rezeki di sawah. Hal ini dilakukan bukan degan tujuan untuk menggagalkan pendidikan anak-anak mereka. Akan tetapi, mereka memberi bekal agar kelak di kemudian hari di mana agar anak-anak mereka dapat memiliki pengalaman untuk bisa mandiri. Mereka pun juga melakukan hal ini agar anak-anak mereka dapat memahami sawah beserta dengan isinya, dan juga dapat bersahabat dengan sawah.

Para orang tua yang berprofesi sebagai buruh tani di Desa Bayu Urip , bahwa mengajak anak-anak mereka untuk belajar mengenal sawah adalah sesuatu yang berharga bagi mereka. Mereka beranggapan bahwa sawah adalah sumber penghidupanku. Hal inilah yang menyebabkan jika sedini mungkin mereka memperkenalkan sumber penghidupan yang layak bagi mereka yaitu dari bertani.

Beberapa orang tua yang berprofesi sebagai buruh tani berpendapat bahwa sekolah itu tetap penting bagi anak-anak mereka. Sekolah adalah lingkungan pendidikan formal yang dapat membantu anak-anak mereka agar kelak dapat menjadi orang-orang terdidik. Mereka pun juga berpendapat bahwa dengan melalui pendidikan formal, yang mana sebagai generasi penerus bangsa tentu dapat menjaga kelestarian lingkungan, dan bahkan dapat memikirkan sumber penghidupan dari pertanian dengan mengkolaborasikan antara ilmu yang diperoleh dari sekolah dengan pengalaman yang pernah didapat dari orang tua mereka ketika diajak ke sawah.

Pendidikan di sekolah merupakan lingkungan formal yang dapat memberi sejuta ilmu pengetahuan bagi anak-anak. Selain itu, lingkungan sekolah juga sangat berperan penting terhadap pembentukan karakter anak-anak mereka. Itulah sebabnya mereka sangat memiliki motivasi tinggi untuk tetap menyekolahkan anak- anak mereka. Jikalau mereka mengajak anak-anak mereka untuk belajar bertani, itu hanya beberapa kali saja, namun para orang tua buruh tani tetap meminta izin pada pihak skolah. Selain itu, para orang tua pun tetap akan berusaha agar anakanak mereka dapat diberikan tambahan pelajaran dari sekolah jikalau mereka pernah mengajak anak-anak mereka bertani sehingga meninggalkan jam pembelajaran di sekolah.

Abduh $\left(35^{\text {th }}\right)$ mengatakan bahwa dirinya pernah megajak seorang anak lakilakinya untuk untuk mengenal situasi mencari rezeki di sawah. Akan tetapi, ia pun mengakui bahwa dirinya tetap mengarahkan anaknya agar bisa mengikuti proses pembelajaran dengan baik. Bakan ia pun bercita-cita untuk menyekolahkan anaknya ke jenjang pendidikan yang lebih tinggi. Kalaupun dirinya mengajak anaknya ke sawah, itu atas perizinan dari pihak sekolah, dan hanya dalam waktu satu hari saja. Akan tetapi, Anwar tetap akan meminta tugas tambahan dan bimbngan agar anak tersebut dapat mengejar mata pelajaran yang tertinggal.

Hal di atas, tentu mencerminkan bahwa warga nelayan yang ada di Desa Banyu Urip memiliki tujuan positip ketika mengajak anak-anak mereka ke sawah. Mereka berpikir bahwa dengan mengajak anak-anak mereka untuk bersawah adalah suatu proses pendidikan masyarakat yang dapat diperoleh melalui orang tua di suatu tempat kerja. Namun para orang tua yang berprofesi sebagai buruh tani tetap saja termotivasi untuk menyeolahkan anakanak mereka, dan menginginkan anakanak mereka sukses di jalur pendidikan.

Hal serupa yang disampaikan oleh Zainudin (25 th) bahwa walaupun sering mengajak anaknya untuk belajar bersawah, namun dirinya tetap memotivasi anaknya agar tetap memperhatikan pendidikan di sekolah. Persoalan pernah meninggalkan proses pembelajaran di sekolah untuk satu atau dua hari, itupun bukan berarti mempengaruhi seorang anak untuk bolos, 
akan tetapi hanya terjadi pada saat tertentu, yaitu ketika sangat membuthkan anggota di atas perahu, sehingga terpaksa ia harus mengajak anaknya, dan itu pun atas seizin pihak sekolah.

Hal di atas dapat dipahami bahwa kodisi itu memang selalu hadir dalam roda kehidupam. Fathurrahman (40 tahun) mengajak seorang anak untuk belajar bersawah adalah bukan karena dengan kesengajaan untuk meninggalkan pembelajaran di sekolah, melainkan pada kondisi tertentu, yaitu tatkala orang tua membutuhkan seorang teman untuk melaut dan tidak ada orang lain, akhirnya ia pun mengajak anaknya sendiri sembari membelajarkan anaknya untuk memamahami laut dan seluruh isinya, Abdullah juga berpikir bahwa dengan adanya pengalaman melaut bagi seorang anak tentu merupakan pengalaman berharga bagi seorang anak sebab menjadi bekal pada masa depannya nanti ketika sulit untuk mencari sumber penghidupan yang lain. Di sisi lain, Abdullah tetap berusaha agar anaknya tetap akan memperhatikan pendidikan di sekolah dengan baik.

Hasen (45 th) juga menyampaikan bahwa " Sekolah itu adalah penting, dan nomor satu bagi anak. Sebab dengan pendidikan tentu akan memberi pelajaran kepada anak agar kelak akan memliki keperibadian yang baik. Selain itu dengan pendidikan tentu anak itu akan cakap dan cerdas dalam menyikapi suatu persoalan, apalagi di zaman moderen seperti ini," ungkapanya. Olehnya itu, bagi seorang Hasen bahwa walaupun dirinya selalu melaut untuk beberapa minggu lamanya, akan tetapi dirinya pun tetap menginginkan anak-anaknya untuk tetap memperhatikan sekolah, bahkan di saat ia kembali ke rumah ia pun selalu memotivasi anak-anaknya agar tetap rajin pergi ke sekolah, dan juga selalu memberi peringatan kepada anak-anaknya agar tidak lupa mengerjakan tugas pelajaran sebelum tidur.
Dari pernyataan di atas dapat disimpulkan bahwa walaupun seorang orang tua yang sama sekali sulit untuk selalu berkumpul bersama keluarga, termasuk memperhatikan keberadaan seorang anak secara langsung, akan tetapi seorang Hasen, ia pun tetap menomorsatukan pendidikan bahkan dirinya tak mau melihat jikalau anak-anakanaknya gagal pendidikan.

Keberadaan ibu-ibu buruh tani juga sangat disibukkan oleh waktu, terutama ketika akan membantu suami di sawah, termasuk membawakan makanan. Namun dalam kenyataanya, bahwa sesibuk apaupun mereka, namun tetap saja mendampingi anak-anak mereka di rumah, bahkan mengajak di tepi pematang sawah untuk menyaksikan sang suami yang sedang bekerja. Dalam hal pendidikan, para ibu-ibu nelayan yang ada di Desa Banyu Urip, yang mana mereka pun senantiasa mendorong agar anak-anak mereka tetap rajin ke sekolah. Pada waktu pagi pun, para ibu-ibu nelayan terkadang mengantar anak-anak mereka yang masih berusia kecil ke sekolah.

Hal diatas tentu menunjukkan bahwa motivasi ibu-ibu, khususnya yang berperan sebagai ibu-ibu nelayan juga masih sangat termotivasi terhadap pendidikan anak-anak mereka. Mereka cinta pendidikan, sehingga mereka memperhatikan anak-anak mereka hingga memasuki area sekolah.

Sumarni (41 tahun) mengatakan bahwa jikalau seorang anak terlambat bangun, ia pun langsung membangunkan hingga mengurus semua perlengkapan sekolahnya. Ia pun juga terkadang mengantar seorang anak menuju ke depan pintu gerbang sekolah agar dirinya tahu kalau anaknya itu benar-benar datang untuk menuntut ilmu pendidikan melalu bangku sekolah.

Hal ini pula tentu menggambarkan bahwa peran ibu-ibu nelayan juga andil untuk meraih rezeki di pulau ini, akan tetapi mereka pun tetap berkeinginan atau 
termotivasi untuk memperatikan pendidikan anak-anak mereka. Mereka pun termotivasi untuk mendorong anak-anak mereka ke sekolah, akan tetapi bukan karena dorongan orang lain namun melainkan motivasi yang muncul dari drinya sendiri.

Selain hal di atas, yang mana berdasarkan dari segi pengamatan bahwa walaupun masyarakat Desa Banyu Urip memiliki aktifitas sebagai buruh tani, dan mereka tetap bisa menjalin hubungan yang harmonis dengan anggota keluarganya, terutam dengan anaknya, mereka pun tetap memperhatikan pendidikan anak-anak mereka, Mereka pun tetap memiliki antusiasme agar anak-anak mereka menyentuh pendidikan dengan melalui pendidikan formal atau sekolah. Keikutsertaan seorang anak pada orang tua untuk ke sawah, itu pun disesuaikan dengan kondisi, namun tetap mereka berusaha agar dapat mengejar ketertinggalan pelajaran.

Dari hasil pengamatan tersebut di atas, dapat disimpulkan pula bahwa sesibuk apapun masyarakat buruh tani yang ada di Desa Banyu Urip, yaitu khususnya dalam melaksanakan aktifitas keseharian mereka, namun mereka tetap berusaha untuk membelajarkan anak-anak mereka melalui pendidikan formal atau sekolah. Mereka tetap memperhatikan dan berusaha agar anak-anak mereka akan sukses melalui jalur pendidikan. Selain itu, mereka pun mengingkan agar anak-anak mereka akan pintar dan cerdas sehngaga dapat memperhatikan dan melestarikan kondisi pertanian. Bahkan orang tua buruh tani yang ada di Banyu Urip beranggapan bahwa dengan adanya pendidikan yang diperoleh melalui bangku sekolah, di mana anak-anak mereka kelak mampu untuk menyelesaikan tantangan hidup yang ada.

Berdasarkan hasil wawancara dan pengamatan yang ada di Desa Banyu Urip, yaitu khususnya tentang motivasi orang tua yang berprofesi sebagai buruh tani terhadap pendidikan, yang mana dapat digeneralisasikan bahwa bahwa walaupun mereka jarang bertemu dengan anak-anak mereka di lingkungan keluarga, akan tetapi mereka tetap termotivasi untuk menyekolahkan anak-anak mereka, bahkan mereka berkeinginan agar anak-anak mereka memiliki pendidikan yang sangat tinggi. Demikian juga pada ibu-ibu buruh tani lainnya, bahwa sesibuk apaun mereka, mereka tetap dapat mengontrol pendidikan anak-anak mereka, bahkan mereka selalu termotivasi agar anak-anak mereka mengerjakan tugas-tugas yang telah diberikan dari sekolah. Mereka pun juga selalu berpesan kepada anak-anak mereka agar tetap rajin dalam memperhatikan pendidikan di sekolah. Sejatinya bahwa baik orang tua laki-laki mauupun orang tua perempuan yang juga berorofsesi sebagai ibu-ibu buruh tani, yang mana mereka memliki motivasi yang tinggi untuk tetap menyekolahkan anak-anak mereka. Suatu alasan bahwa pendidikan adalah suatu langkah yang baik terhadap pembentukan kepribadian anak. Alasan lain adalah bahwa dengan pendidikan seorang anak akan berwawasan sehingga kelak mampu menjawab berbagai macam tantangan hidup yang ada.

\section{B. Bentuk Motivasi Orang Tua Buruh Tani Tehadap Pendidikan Anak}

Ada dua jenis atau bentuk motivasi sehingga seseorang akan mampu melakukan sesuatu. Kedua bentuk tersebut adalah motivasi intrinsik dan motivasi eksternal. Pada orang tua yang berprofesi sebagai buruh tani, yang mana mereka termotivasi untuk tetap memperhatikan pendidikan anak karena atas kesadaran sendiri. Merujuk pada Ibrahim (2003:28) tentang motivasi intrinsik, yang mana motivasi intrinsik dapat muncul karena salah satunya adalah faktor kesadaran diri sendiri dengan tujuan yang esensial atau seremonial. Para orang tua yang berprofesi sebagai buruh tani yang ada di Desa Banyu Urip, mereka sangat memahami arti sebuah pendidikan formal terhadap pembentukan keperibadian anak. Hal 
inilah yang menyebakan mereka memiliki motivasi instrinsik sehingga mereka sangat antusias untuk tetap menyekolahkan anakanak mereka.

Minat, cita, dan hasrat ingin tahu adalah hal yang dapat membangkitkan motivasi instrinsik pada seseorang. Minat pada orang tua yang berprofesi sebagai nelayan di Banyu Urip sangat tinggi karena mereka didasari suatu kebutuhan, yaitu menginginkan anak-anak mereka untuk bisa memiliki kepribadian yang baik, serta kelak akan mampu menghadapi berbagai macam tangan hidup.

Seorang Agus Salim mengatakan bahwa dirinya menginginkan anak-anak yang ada di Desa Banyu Urip memilki ilmu pengetahuan yang cukup tinggi agar kelak mampu untuk menjawab berbagai tantangan hidup di tengah era golobalisasi moderen, khususnya dalam membangun daerah, khususnya membangun Desa Banyu Urip sebagai desa hijau. Artinya bahwa dengan pendidikan formal sudah barang tentu anak-anak Banyu Urip di kemudian hari akan lebih bersikap dewasa dalam menghadap berbagai tantangan hdup, apalagi pada zaman sekarang, yang mana tekonologi moderen semakin pesat. Tentu dalam hal memberi arti bahwa efek dari teknologi modern tersebut sangat tinggi, sehingga dengan melalui jalur pendidikan formal di mana anak-analk dari Banyu Urip di kemudian hari mampu mengatasi berbagai persoalan-persoalan hidup yang ada, khususnya pula dalam memperhatikan kondisi pertanian yang ada di sekitar Banyu Urip yang notabenenya sebagai sumber mata pencaharian utama bagi masyarakat di wilayah ini.

Dari gambaran di atas dapat disimpulkan bahwa bentuk motivasi orang tua yang berrofesi sebagai buruh tani terhadap pentingnya pendidikan anak adalah muncul dari kesadaran diri sendiri, dan juga karena sesuatu yang sangat dibutuhkan pada generasi penerus bangsa yaitu agar anak-anak tersebut, khusnya yang ada di Desa Banyu Urip memiliki tingkat pendidikan yang lebih tinggi sehingga kelak di kemudian hari dapat hidup secara mandiri. Selain itu, mereka mengharapkan agar anak-anak Desa Banyu Urip memiliki keperibadian baik, dan mampu menjawab berbagai tantangan hidup kelak di tengah maraknya teknologi moderen yang memiliki dampak negatif. Hal inilah yang mempengaruhi para orang tua yang berprofesi sebagai buruh tani di Banyu Urip termotivasi secara instrinsik untuk memperhatikan penadikan anak.

\section{KESIMPULAN}

1. Motivasi orang tua buruh tani terhadap pendidikan anak di Desa Banyu Urip Kecamatan Praya Barat Kabupaten Lombok Tengah adalah sangan baik, dalam arti walaupun mereka disibukkan oleh waktu di laut namun tetap memperhatikan pendikan anakanak mereka

2. Bentuk motivasi orang tua yang berprofesi sebagai buruh tani terhadap pendidikan anak di Desa Banyu Urip Kecamatan Praya Barat Kabupaten Lombok Tengah muncul dari dalam atau atas kesadaran sendiri sehingga mereka benar-benar menginginkan agar anak-anak mereka tetap aktif dalam mengikuti proses pembelajaran dengan melalui jalur pendidikan formal atau sekolah.

\section{SARAN}

1. Agar para orang tua dalam bebagai kelompok kerja dapat memperhatikan pendidikan anak, karena dengan pendidikan tentu anak-anak tersebut kelak akan menjadi manusi yang lebih dewasa dalam bersikap.

2. Agar pemerintah lebih giat dalam memperhatikan betapa pentingnya pendidikan terhadap pembentukan menuju kdewasaan.

3. Agar pada masyarakat, khususnya bagi anak-anak bangsa agar dapat lebih memahami pentingnya pedidikan karena dengan pendidikan tentu akan 
membentuk suatu kepribadian ke arah yang lebih baik.

\section{DAFTAR PUSTAKA}

Ahmad Tanzeh, Pengantar Metode Penelitian, (Yogyakarta: Teras, 2009).

Firman Abdullah, Tanggung Jawab Orang Tua Dalam Pendidikan Anak, (Semarang: Pelita Ibu,1988).

Husaini Usman dan Purnomo Setiadi Akbar, "Metode Penelitian Sosial"(Jakarta: Bumi Aksara, 1996).

M. Idrus, Metode Penelitian Ilmu-ilmu Sosial: Pendekatan Kualitatif dan Kuantitatif, (Yogyakarta: UII Press, 2007).

Sardiman, Interaksi dan Motivasi Belajar (Jakarta: Raja Grafindo Persada, 2001).

Siti Partini Sudirman, "Psikologi Pendidikan", (Bandung: PT. Remaja Rasda Karya, 1990).

Slameto. Belajar Dan Faktor-Faktor Yang Mempengaruhi, Jakarta : Rineka Cipta 1995.

Sudirman ,"Bimbingan Orang Tua Dan Anak, Yogyakarta: Percetakan Studing 1984.

Sumadi Suryabrata, " Beberapa Prinsip Psikologi Pendidikan”, (Yogyakarta: Fakultas Psikologi UGM).

Ahmad Tanzeh, Pengantar Metode Penelitian, (Yogyakarta: Teras, 2009).

Firman Abdullah, Tanggung Jawab Orang Tua Dalam Pendidikan Anak, (Semarang: Pelita Ibu,1988).

Husaini Usman dan Purnomo Setiadi Akbar, "Metode Penelitian Sosial"( Jakarta: Bumi Aksara, 1996).

M. Idrus, Metode Penelitian Ilmu-ilmu Sosial: Pendekatan Kualitatif dan Kuantitatif, (Yogyakarta: UII Press, 2007).
Sardiman, Interaksi dan Motivasi Belajar (Jakarta: Raja Grafindo Persada, 2001).

Siti Partini Sudirman, "Psikologi Pendidikan", (Bandung: PT. Remaja Rasda Karya, 1990).

Slameto. Belajar Dan Faktor-Faktor Yang Mempengaruhi, Jakarta : Rineka Cipta 1995.

Sudirman ,'Bimbingan Orang Tua Dan Anak, Yogyakarta: Percetakan Studing 1984.

Sumadi Suryabrata, " Beberapa Prinsip Psikologi Pendidikan", (Yogyakarta : Fakultas Psikologi UGM). 